\title{
Differences in Caveolae Dynamics in Vascular Smooth Muscle Cells of Different Phenotypes
}

\author{
Johan Thyberg \\ Department of Cell and Molecular Biology, Medical Nobel Institute, Karolinska Institutet, Stockholm, Sweden
}

\begin{abstract}
SUMMARY: Vascular smooth muscle cells shift between two major differentiated states with distinct morphological and functional properties, a contractile and a synthetic phenotype. Here, primary cultures were used to study caveolae expression and dynamics in these cells. The results demonstrate that caveolae are more numerous and more actively interact with intracellular organelles in contractile than in synthetic cells. Immunohistochemistry showed that caveolin-1 was mainly localized to caveolae in contractile cells and partly shifted to Golgi-associated vesicles in synthetic cells, whereas caveolin-2 chiefly appeared in cytoplasmic vesicles in both cases. Cholera toxin $B$ subunit, a ligand of $\mathrm{G}_{\mathrm{M} 1}$ ganglioside, was internalized via caveolae and carried to endosomes and Golgi-associated vesicles. In contractile cells, it later moved into Golgi and endoplasmic reticulum (ER) cisternae and thus had access to the entire endocytic and exocytic pathways. In contrast, in synthetic cells, the tracer was restricted to the endocytic pathway. Filipin staining similarly disclosed that cholesterol was more widely distributed in contractile than in synthetic cells, with strong labeling of both caveolae and adjacent ER portions. Although no direct continuity between caveolae and ER was detected, it is suggested that cholesterol and other molecules may be translocated between these compartments. The observed differences in caveolae expression and dynamics are likely to be significant for the differences in proliferative capacity and cholesterol transport between contractile and synthetic smooth muscle cells. (Lab Invest 2000, 80:915-929).
\end{abstract}

$C$ aveolae are small invaginations of the plasma membrane with key functions in signal transduction (Anderson, 1998; Smart et al, 1999) and lipid transport (Fielding and Fielding, 1997). They are found in cells of both mesenchymal and epithelial origin and are especially abundant in endothelial cells and smooth muscle cells of blood vessel walls. Biochemically, caveolae represent a subdomain of the plasma membrane enriched in cholesterol, glycosphingolipids, and the protein caveolin (three mammalian isoforms have been described). Caveolin is organized as oligomers in the membrane and creates a scaffold on which a variety of signaling molecules is brought together in preassembled signaling complexes (Smart et al, 1999). Furthermore, caveolin binds cholesterol directly (Murata et al, 1995) and takes part in shuttling of free cholesterol between the endoplasmic reticulum (ER), the Golgi complex, and the cell surface (Conrad et al, 1995; Fielding and Fielding, 1996; Smart et al, 1996; Uittenbogaard et al, 1998). Efflux of cellular free cholesterol from cells is likewise believed to occur via caveolae (Fielding and Fielding, 1995). Clathrincoated pits constitute another functionally important part of the plasma membrane. In this case, clathrin

Received March 1, 2000.

This work was supported by grants from the Swedish Medical Research Council, the Swedish Heart Lung Foundation, the King Gustaf V 80th Birthday Fund, the Magn. Bergvall Foundation, and Karolinska Institutet. Address reprint requests to: Dr. J. Thyberg, Department of Cell and Molecular Biology, Medical Nobel Institute, Karolinska Institutet, Box 285, S-171 77 Stockholm, Sweden. Fax: 46830 1833; E-mail johan.thyberg@cmb.ki.se and adaptor proteins are responsible for budding of vesicles that transport macromolecules from the extracellular fluid into the cell (Marsh and McMahon, 1999; Mellman, 1996). One example is receptormediated endocytosis of low density lipoprotein (LDL), a particle that carries cholesterol into cells (Brown and Goldstein, 1986). Clathrin is also involved in sorting and transfer of newly synthesized lysosomal enzymes from the trans-Golgi network to endosomes (Gu and Gruenberg, 1999).

Smooth muscle cells build up the arterial media, and are differentiated cells that contract in response to chemical and mechanical stimuli (a contractile phenotype). After vascular injury and in the early stages of atherogenesis, smooth muscle cells adopt a more immature state, resembling that observed during vasculogenesis (a synthetic phenotype). This dedifferentiation includes a loss of myofilaments and formation of a prominent ER and Golgi complex. Therefore, the cells lose their contractility and become competent to migrate from the media to the intima, proliferate, and secrete extracellular matrix components. A similar modification takes place when smooth muscle cells are put in culture (Owens, 1995; Thyberg, 1996, 1998). Notably, the number of caveolae was found to be distinctly reduced when smooth muscle cells shift from a contractile to a synthetic phenotype. Despite that, the levels of caveolin remained unaltered, and the protein was redistributed from the plasma membrane to the perinuclear cytoplasm (Thyberg et al, 1997). This phenotype-dependent variation in expression of caveolae is likely to be functionally important. It may influence the way in which the cells handle excess 
lipoprotein cholesterol, for instance. Thus, contractile cells were noted to deposit lipids in myelin-like configurations outside caveolae when exposed to LDL. Under the same conditions, synthetic cells accumulated lipid droplets in the cytoplasm (Thyberg et al, 1998). These findings suggest that caveolae have a higher capacity to discharge lipids in contractile than synthetic smooth muscle cells. This may explain why synthetic cells in the arterial intima give rise to lipidfilled foam cells during atherogenesis, whereas contractile cells in the media do not.

Here, the expression and dynamics of caveolae in vascular smooth muscle cells of different phenotypes have been examined in further detail. For this purpose, 1- to 2-day-old (mainly contractile cells) and 3- to 4-day-old primary cultures (mainly synthetic cells) were compared. The distribution of caveolin-1, -2, -3, and clathrin in the cells was analyzed by immunofluorescence and immunoelectron microscopy and the distribution of cholesterol was analyzed by staining with the sterol-binding and fluorescent polyene filipin (Börnig and Geyer, 1974; Kruth and Vaughan, 1980). Binding and uptake of LDL was examined using fluorescently labeled lipoprotein, and the effects of LDL on the number of plasma membrane caveolae was examined by electron microscopy. Internalization and intracellular trafficking of caveolae membrane components were studied using cholera toxin $B$ subunit linked to horseradish peroxidase (CTB-HRP). The $\mathrm{G}_{\mathrm{M} 1}$ ganglioside functions as cellular receptor for cholera toxin and is concentrated in caveolae (Critchley et al, 1982; Parton, 1994). Moreover, cholera toxin is taken up via caveolae and not via coated pits, which are otherwise the most frequent gate for receptor-mediated uptake of specific ligands (Lencer et al, 1999; Montesano et al, 1982; Tran et al, 1987).

\section{Results}

\section{Phenotypic Modification of Smooth Muscle Cells in Primary Culture}

The primary culture system was established as an experimental model for study of the principal shift in phenotype of vascular smooth muscle cells (Thyberg, 1996). Cells isolated from the rat aortic media retained a differentiated, contractile phenotype for at least 1 to 2 days in culture, as revealed by the predominance of myofilaments, the paucity of secretory organelles, and the abundance of plasma membrane caveolae (Fig. $1 \mathrm{~A})$. During the next few days, most of the cells went through a structural reorganization and lost a large number of their myofilaments. In parallel, an extensive ER and a large Golgi complex were built up. Moreover, caveolae were reduced in number, but remained more numerous than coated pits (Fig. 1B). Cells which were not modified in this manner died (partly by apoptosis), and 4 to 5 days after seeding the majority of the cells were in a synthetic phenotype. In this respect, no differences were seen between cells seeded on a substrate of fibronectin in serum-free medium and cells seeded in plastic dishes in serum-containing medium. However, it was only in the latter cultures that an active cell proliferation followed on the shift in phenotype (Hedin et al, 1988; Thyberg et al, 1983).

\section{Immunoreactivity for Caveolin and Clathrin}

Immunofluorescence microscopy was used to gain an overview of caveolin and clathrin distribution in the cells. Immunohistochemistry was also used to examine the Golgi complex (mannosidase II), actin filaments (smooth muscle $\alpha$-actin or rhodamine-phalloidin), and microtubules ( $\alpha$-tubulin). In 1-day-old cultures, caveolin-1 antibodies showed immunoreactivity with dispersed spots and a few larger vesicles (Fig. 2A). Caveolin-2 antibodies gave a weaker reaction, but some cells contained positive vesicles scattered around the nucleus (Fig. 2B). Clathrin antibodies yielded a weak reaction with dispersed spots (Fig. 2C). In 4-day-old cultures, the caveolin-1 and -2 immunoreactivities were reduced and shifted toward a Golgilike pattern (Fig. 2, D and E). In addition, clathrin now showed a more Golgi-like pattern (Fig. 2F). Caveolin-3 antibodies showed weak immunoreactivity resembling that for caveolin-1 at both times (data not shown). Mannosidase II revealed a juxtanuclear network that grew in size from day 1 to 4 (Fig. 3, A and D). This agrees with electron microscopic observations of an increase in number and size of the Golgi stacks during the transition into a synthetic phenotype (Thyberg et al, 1983). Smooth muscle $\alpha$-actin was organized in stress fibers and all cells were immunoreactive at early times in culture (Fig. 3B). The filamentous staining for $\alpha$-actin decreased at later times (Fig. 3E), but phalloidin-binding stress fibers were still found, indicating that a shift in actin isoforms had occurred. Tubulin staining revealed an extensive microtubule system both in 1- and 4-day-old cultures (Fig. 3, C and $F$ ).

As part of the basic characterization of the smooth muscle cells, efforts were further made to study the localization of caveolin by immunoelectron microscopy. A complication in this work was that caveolae were difficult to detect morphologically without postosmication. Therefore, a modified preparation protocol with a mild osmium postfixation was applied. This made it easier to identify caveolae but at the same time reduced the antigenicity of the cell sections. For example, the reactivity to antibodies against smooth muscle $\alpha$-actin, a differentiation marker for contractile cells, was impaired after osmium treatment (Fig. 4, A and $\mathrm{B}$ ). The immunoreactivity to caveolin antibodies was also weak. However, it was possible to see labeling of plasma membrane invaginations in contractile cells and labeling of Golgi-associated vesicles in synthetic cells. Similar results were obtained with polyclonal (Fig. 4, C and D) and monoclonal caveolin antibodies (Fig. 4, E and F).

\section{Cellular Uptake of BODIPY FL LDL}

To compare the ability of cells of different phenotypes to internalize LDL, primary cultures of varying age 

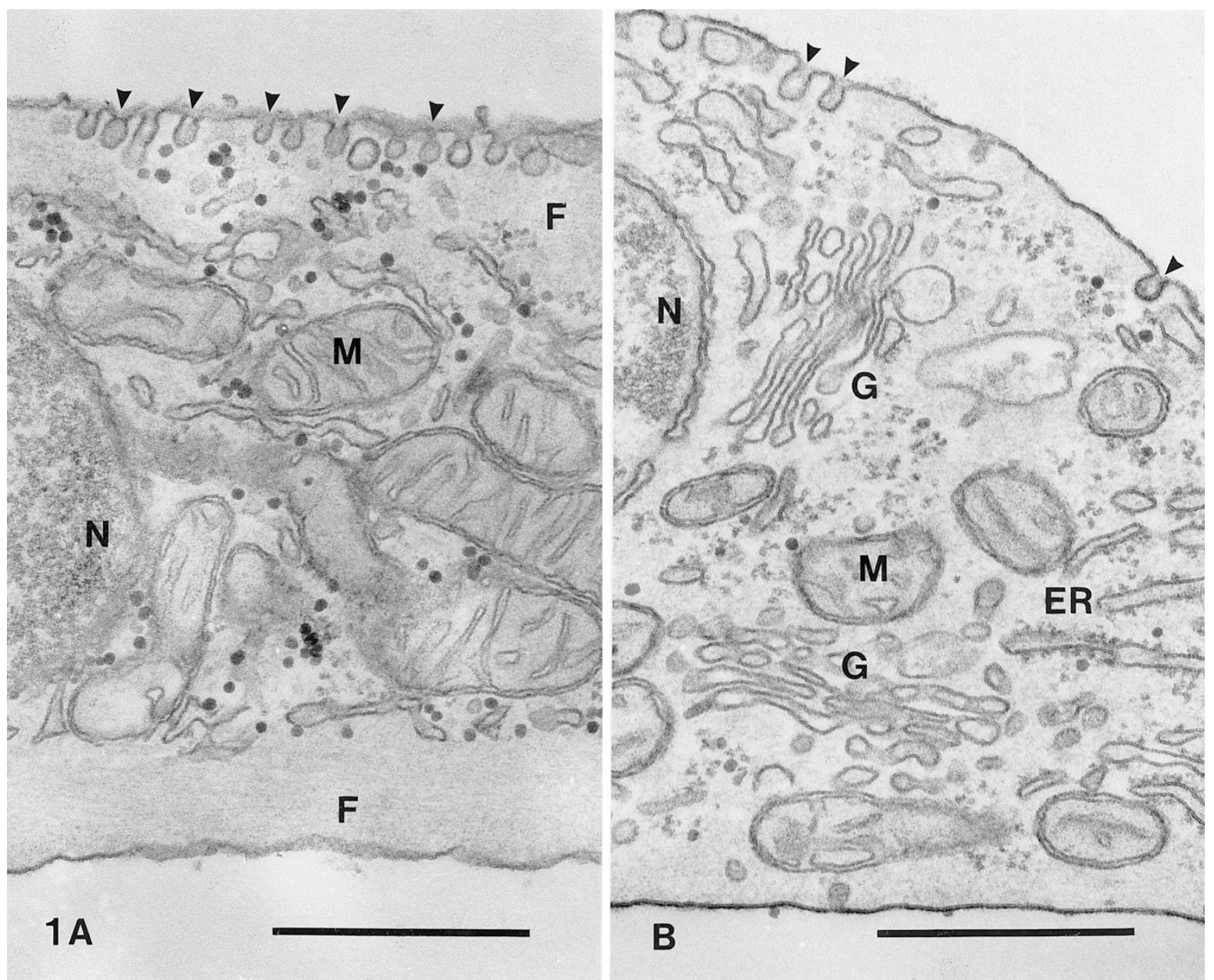

\section{Figure 1.}

Electron microscopy of smooth muscle cells from 1-day-old (A) and 4-day-old (B) primary cultures grown in $\mathrm{F} 12$ medium with 10\% newborn calf serum (NCS). The cells are in a contractile phenotype (A) and a synthetic phenotype (B), respectively. Arrowheads mark caveolae. ER, endoplasmic reticulum; $F$, myofilaments; $G$, Golgi stacks; $M$, mitochondria; $N$, nucleus. Scale bars $=0.5 \mu \mathrm{m}$.

were exposed to BODIPY FL LDL $(50 \mu \mathrm{g} / \mathrm{ml}$ for 90 minutes) and studied by fluorescence microscopy. In both 1- and 4-day-old cultures, the cells bound and ingested labeled LDL. This was seen as small dispersed vesicles and larger vacuoles accumulated in the perinuclear cytoplasm (Fig. 5, A and B). An equivalent but weaker immunoreactivity was obtained if the cells were first exposed to labeled LDL for 60 minutes at $4^{\circ} \mathrm{C}$ to allow receptor binding, rinsed three times with cold medium, and then incubated at $37^{\circ} \mathrm{C}$ for 60 minutes. No marked differences were observed between cells grown on a substrate of fibronectin in serum-free medium and cells grown in plastic dishes in serum-containing medium. Four separate experiments were made with similar findings.

\section{Filipin Staining}

An overview of cholesterol in the cells was gained by filipin staining and fluorescence microscopy. In primary cultures grown in serum-containing medium for 3 days (mix of contractile and synthetic cells), a perinuclear, Golgi-like pattern was seen. Moreover, fluorescent plaques of variable size occurred in the cell periphery, and a fine punctate immunoreactivity, possibly representing the plasma membrane, covered the cells (Fig. 6). A more detailed view of intracellular cholesterol was achieved by using filipin as an electron microscopic probe. The multimolecular complexes that form when filipin interacts with membrane cholesterol give the membranes a 'scalloped' appearance (Orci et al, 1981). In both contractile and synthetic cells, plasma membrane labeling was found not only in connection with caveolae but also over other regions (Fig. 7, A to D). The staining of caveolae was concentrated around their openings on the cell surface and not the invaginated part of the membrane. A similar pattern has been observed in capillary endothelial cells (Simionescu et al, 1983). Especially in contractile cells, a distinct labeling was further detected in peripheral cisternae/tubules of the ER, often showing close contact with caveolae (Fig. 7, B and C). Additional labeling was noted in other parts of the ER, including the nuclear envelope. In the Golgi complex, filipin-sterol complexes were localized to vesicular/ 

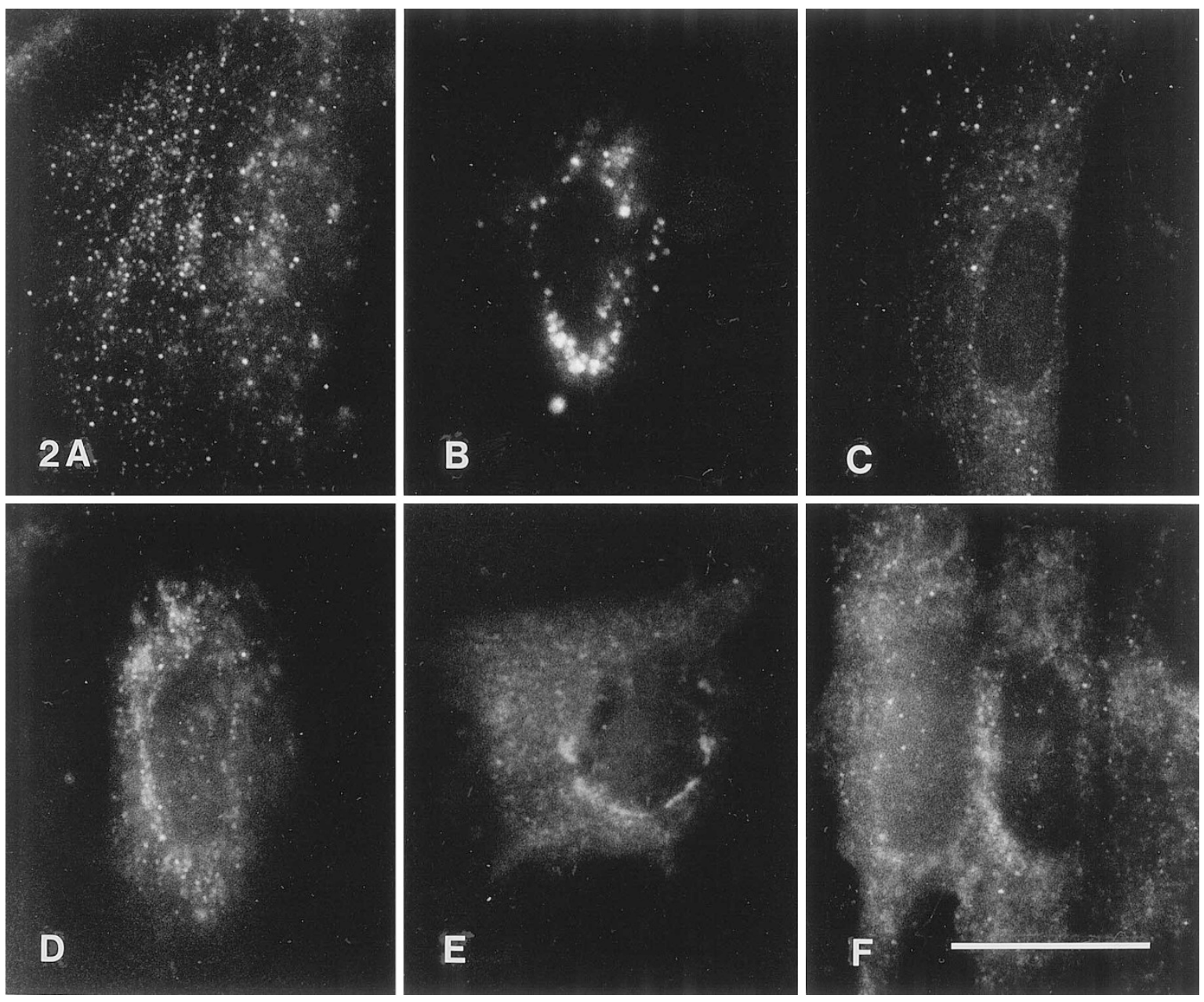

\section{Figure 2.}

Indirect immunofluorescence microscopy of smooth muscle cells from 1-day-old (A, B, and C) and 4-day-old (D, E, and F) primary cultures grown on a substrate of fibronectin in F12 medium with 1\% NCS. Immunoreactivity to primary antibodies against caveolin-1 (A and D), caveolin-2 (B and E), or clathrin heavy chain (C and F). Scale bar $=20 \mu \mathrm{m}$.

tubular profiles, whereas the stacked cisternae seldom were reactive (Fig. 7E). Immunoreactivity in larger endosomes was also observed (Fig. 7E). In cells cultured on a substrate of fibronectin in serum-free medium, the filipin immunoreactivity did not clearly differ from that described above. After incubation of the cells with $\mathrm{LDL}(0.1 \mathrm{mg} / \mathrm{ml}$ for 10 hours), the number of filipin-sterol complexes was increased, but their distribution in the cells remained the same.

\section{Internalization of CTB-HRP}

CTB-HRP bound to the cells at $4^{\circ} \mathrm{C}$ and was found both in caveolae and on the plasma membrane proper. In this respect, no difference occurred between contractile and synthetic cells. After rinsing and warming to $37^{\circ} \mathrm{C}$, the tracer molecules were internalized and then behaved different in the two groups of cells. Equivalent results were obtained if the cells were exposed to the tracer at $37^{\circ} \mathrm{C}$ from the start. After 10 to 30 minutes, caveolae and plasma membrane labeling was decreased, and reactive material appeared in small vesicles ( 50 to $80 \mathrm{~nm}$ ) associated with the Golgi stacks and a few larger endosomes (200 to $500 \mathrm{~nm}$ ). This was the characteristic image in synthetic cells, whereas contractile cells showed additional labeling in Golgi cisternae and tubules. After 60 to 120 minutes, the situation remained the same in synthetic cells (Fig. $8, A$ and $B$ ), and a close spatial relation between reactive vesicles/tubules and microtubules was observed (Fig. 8, C and D). In contractile cells, Golgi cisternae (especially in cis/medial parts of the stacks) and most of the ER (from the nuclear envelope to cisternae/tubules in the cell periphery) were now labeled (Fig. 9, A to D). Staining was further seen in vesicles/tubules between the Golgi stacks and adjacent ER cisternae (Fig. 9, B and C). In contrast, caveolae and the plasma membrane usually remained unlabelled (Fig. 9, A and D). Analogous findings were seen in four experiments. For comparison, the ingestion of HRP alone, a fluid-phase marker, and cationized ferritin (CF), a marker that binds to cell surface glycoconjugates because of its charge, was also studied. With these molecules, similar observations were made in contractile and synthetic cells. HRP and CF 

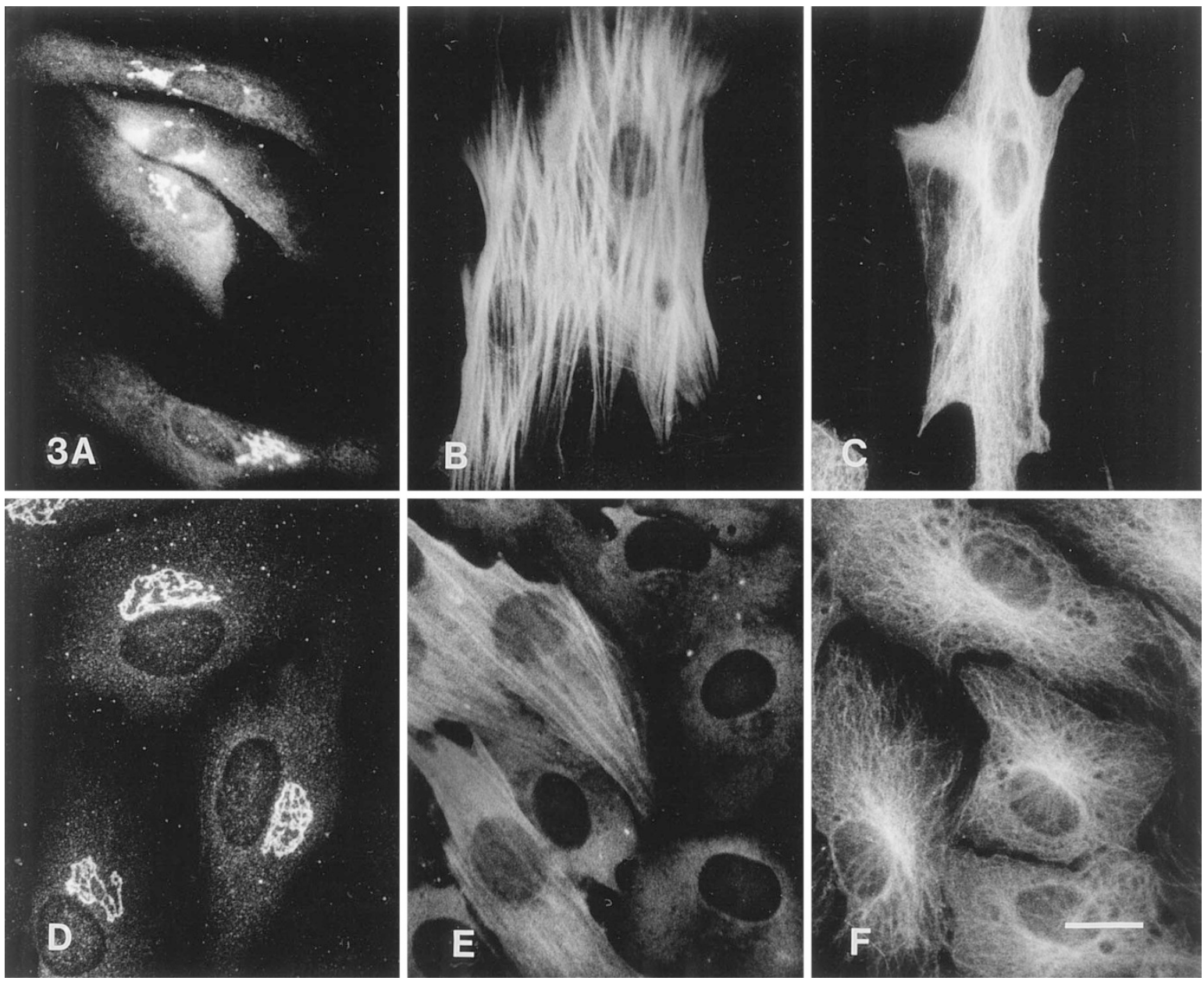

Figure 3.

Indirect immunofluorescence microscopy of smooth muscle cells from 1-day-old (A, B, and $\mathrm{C})$ and 4-day-old (D, E, and F) primary cultures grown in F12 medium with 10\% NCS. Immunoreactivity to primary antibodies against mannosidase II (A and D), smooth muscle $\alpha$-actin (B and E), or $\alpha$-tubulin (C and F). Scale bar = $20 \mu \mathrm{m}$.

were internalized in small vesicles and later gathered in endosomes/lysosomes. A weak labeling of cisternae/tubules on the trans side of the Golgi stacks was sometimes noted. On the other hand, neither HRP nor CF could be detected in stacked Golgi cisternae or in the ER.

\section{Effects of LDL on Caveolae Expression}

To study whether the expression of plasma membrane caveolae was influenced by supplying an excess of cholesterol, the cells were grown on a substrate of fibronectin in F12 medium with 10\% NCS for 1 or 4 days, exposed to LDL $(0.5 \mathrm{mg} / \mathrm{ml})$ in $\mathrm{F} 12$ medium with $0.5 \%$ NCS for 6 to 8 hours, and processed for electron microscopy (six separate experiments). In the quantitative evaluation, the number of caveolae on the upper cell surface was counted (caveolae appeared on the lower substrate-attached surface as well, but in lower and more variable numbers). The results revealed that the density of caveolae was more than 6-fold higher in contractile cells than in synthetic cells. After incubation with LDL, no increase in caveolae number was noted in contractile cells, whereas a doubling occurred in synthetic cells (Table 1). A close relationship between caveolae and ER cisternae was also observed (see Thyberg et al, 1997). In some contractile cells, LDL further induced formation of an extensive system of membrane tubules/cisternae next to clusters of plasma membrane caveolae. In addition, myelin-like deposits appeared both in the cytoplasm and extracellularly, just outside caveolae. Such deposits were lacking in synthetic cells, which instead contained endosomes/lysosomes with myelin-like inclusions and cytoplasmic lipid droplets (Thyberg et al, 1998).

\section{Discussion}

\section{General Comments}

This report extends earlier findings of differences in caveolae expression and cholesterol transport between vascular smooth muscle cells in a contractile and a synthetic phenotype (Thyberg et al, 1997, 1998). The results confirm that caveolae are more numerous 

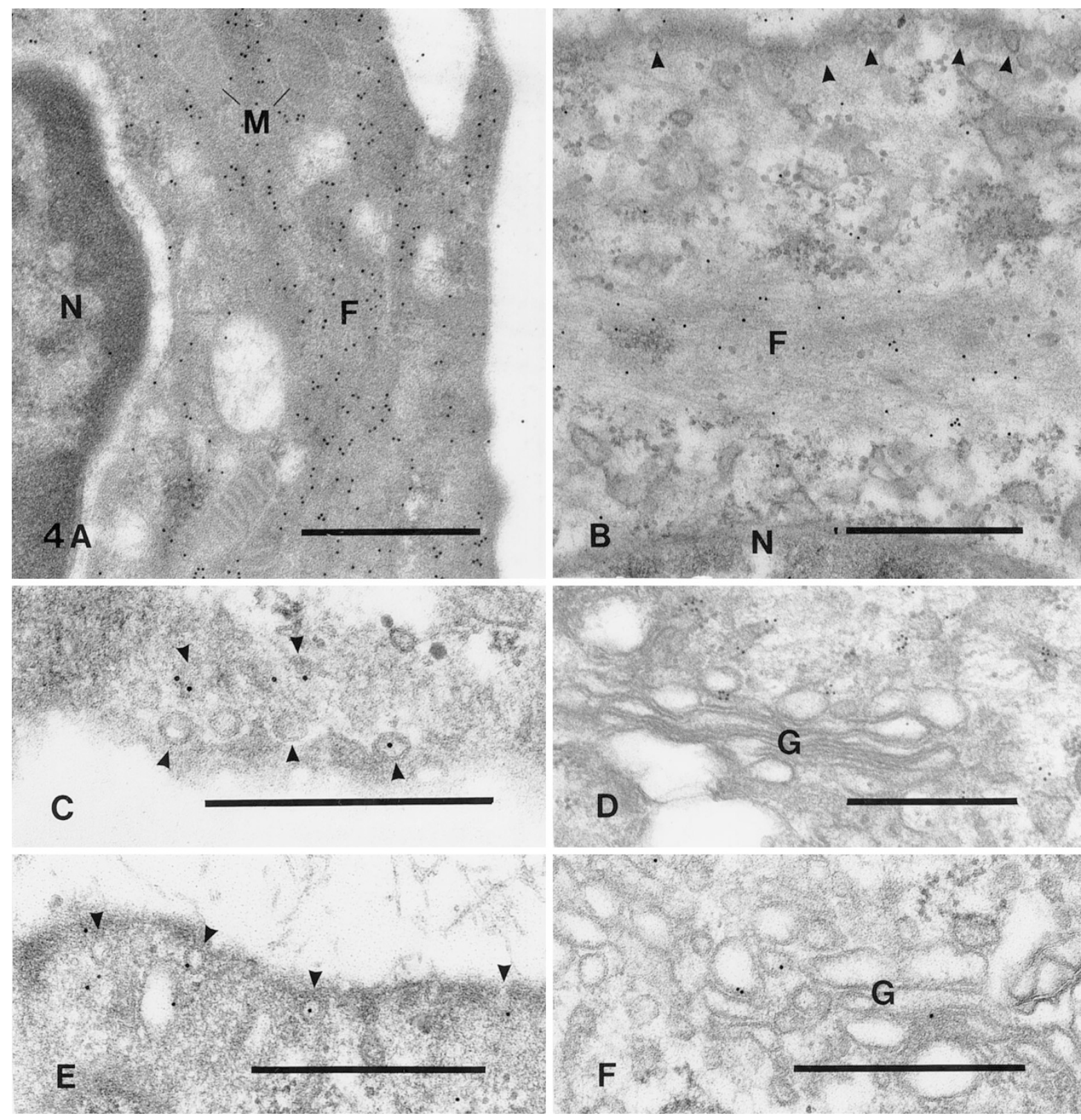

\section{Figure 4.}

Immunoelectron microscopy of smooth muscle cells from 1-day-old (A, B, C, and E) and 4-day-old (D and F) primary cultures grown in F12 medium with 10\% NCS Preparations without $(A)$ and with (B to F) mild postosmication were used (see Materials and Methods). Immunogold reactivity to primary antibodies against smooth muscle $\alpha$-actin ( $\mathrm{A}$ and $\mathrm{B}$ ), caveolin ( $\mathrm{C}$ and $\mathrm{D}$ ), and caveolin-3 (E and $\mathrm{F}$ ). In the absence of postosmication, the labeling with the $\alpha$-actin antibody is strong, but membranes appear in negative contrast and no caveolae are detected on the cell surface (A). After postosmication, the labeling with the $\alpha$-actin antibody is reduced, but caveolae (arrowheads) are now distinguishable (B). F, myofilaments; G, Golgi stacks; $M$, mitochondria; $N$, nucleus. Scale bars $=0.5 \mu$ m.

in contractile than in synthetic cells, and indicate that the dynamics of the caveolae system is higher in the contractile cells. This was particularly evident when studying the uptake of CTB-HRP, a tracer that binds to $G_{M 1}$ ganglioside. Immunohistochemistry with the sterol-binding polyene antibiotic filipin similarly demonstrated that cholesterol was more widely distributed in contractile than in synthetic cells. Of special interest was the appearance of CTB-HRP and filipin-sterol complexes in peripheral ER parts, close to cell surface caveolae. This suggests that a direct interaction between caveolae and the ER may take place. After exposure to LDL, the number of caveolae was in- creased in synthetic cells, but not up to the level normally found in contractile cells. In contractile cells, no additional increase in caveolae number was noted after exposure to LDL. Below, the observations are discussed with emphasis on the possible function of caveolin and caveolae in cholesterol transport.

\section{Caveolae Expression}

The results confirm that caveolae are severalfold more abundant in contractile than in synthetic smooth muscle cells (Thyberg et al, 1997). Immunofluorescence and immunoelectron microscopy further indicated that 

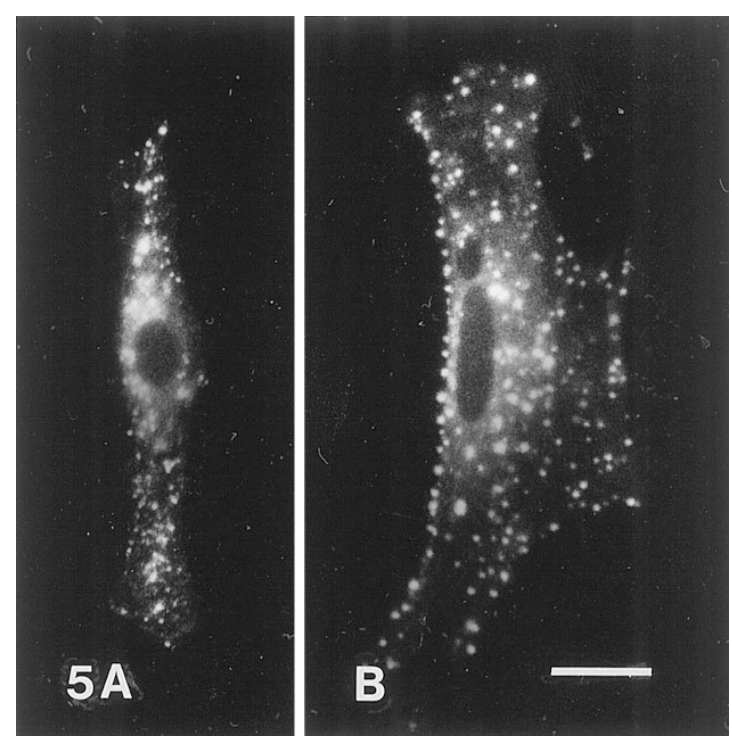

\section{Figure 5 .}

Fluorescence microscopy of smooth muscle cells cultured on a substrate of fibronectin in F12 medium with $0.1 \%$ bovine serum albumin (BSA) for 1 day (A) or 4 days (B), exposed to $50 \mu \mathrm{g} / \mathrm{ml}$ of BODIPY FL LDL for 90 minutes at $37^{\circ} \mathrm{C}$, rinsed three times, and processed for microscopy (see Materials and Methods). Scale bar $=20 \mu \mathrm{m}$.

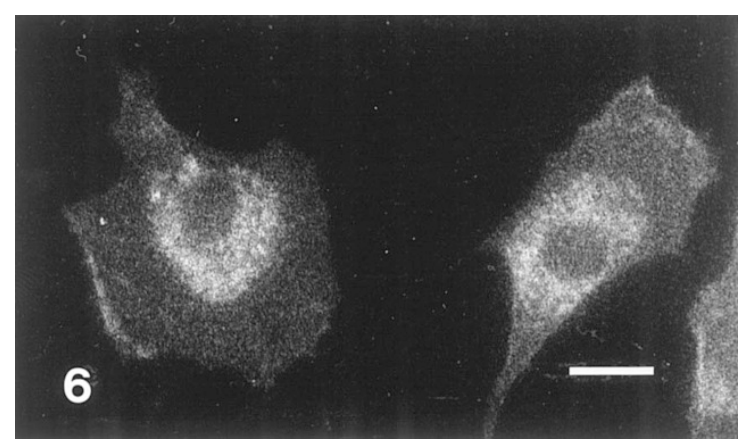

\section{Figure 6.}

Fluorescence microscopy of primary culture stained with filipin. The cells were grown in F12 medium with 10\% NCS for 3 days. After formaldehyde fixation, the cells were incubated with $0.5 \mathrm{mg} / \mathrm{ml}$ of filipin for 15 hours and then examined (see Materials and Methods). Scale bar $=20 \mu \mathrm{m}$.

caveolin-1 is chiefly located on the surface in contractile cells and, in part, transferred to Golgi-associated vesicles in synthetic cells. Caveolin-2 showed weaker immunoreactivity, which was mainly found in Golgi elements both in contractile and synthetic cells. This agrees with recent reports showing that caveolin-1 and -2 are co-expressed in many cells (Scherer et al, 1997) and that caveolin-2 is localized in Golgi but redistributes to caveolae when co-expressed with caveolin-1 (Mora et al, 1999; Parolini et al, 1999). The third isoform, caveolin-3, primarily occurs in skeletal and heart muscle cells, but smaller amounts are also found in smooth muscle cells (Song et al, 1996). Here, the distribution of this protein resembled that of caveolin-1, but with weak immunoreactivity. Why caveolae are more numerous in contractile than in synthetic smooth muscle cells is not clear. Because the overall expression of caveolin are similar in these cells (Thyberg et al, 1997), the level of this protein is not likely to be the explanation. Compared to caveolae, clathrin-coated pits were few, especially in contractile cells. Like caveolin, clathrin was present on the cell surface and in vesicles, reflecting the fact that these proteins are both involved in trafficking between the plasma membrane and cytoplasmic organelles (Anderson, 1998; Gu and Gruenberg, 1999).

\section{Caveolae Dynamics}

Analysis of CTB-HRP uptake revealed that the communication between caveolae and intracellular membrane compartments is more extensive in contractile than in synthetic smooth muscle cells. CTB binds to $\mathrm{G}_{\mathrm{M} 1}$ ganglioside, which is concentrated in caveolae (Parton, 1994), and CTB is preferentially internalized via caveolae (Lencer et al, 1999; Montesano et al, 1982; Orlandi and Fishman, 1998). Accordingly, caveolae possess the molecular machinery for vesicle budding, docking and fusion (Henley et al, 1998; Oh et al, 1998; Schnitzer et al, 1995, 1996). In fibroblasts, CTB was found to follow the same route as ligands taken up via clathrin-coated pits (Tran et al, 1987). In A431 cells, CTB was further transferred to the cisternal stacks of the Golgi complex, but was not observed in the ER (Sandvig et al, 1994). In the synthetic smooth muscle cells, CTB-HRP was ingested via caveolae and then took on a distribution resembling that found in fibroblasts, with labeling of endosomes/lysosomes and Golgi-associated vesicles. In the contractile cells, the tracer was also spread to the Golgi stacks and the ER. Within the stacks, the highest concentration was noted in cis and medial cisternae. Likewise, caveolin was recently reported to be abundant in cis-Golgi and to have a cis-Golgi targeting domain (Luetterforst et al, 1999). In the ER of contractile smooth muscle cells, CTB-HRP was found all of the way from the nuclear envelope to cisternae just inside the plasma membrane. In A431 cells, CTB-HRP was only detected in the ER after depletion of the calcium stores in the ER (Sandvig et al, 1996). Whether calcium levels are important for the variations between synthetic and contractile cells in transport of CTB remains to be determined.

Control experiments with HRP and CF indicated that the widespread dispersal of CTB-HRP in the contractile cells was not due to a high general rate of transport between the endocytic and exocytic pathways. Rather, it seemed that there was a specific routing of $G_{M 1}$ ganglioside and other caveolae membrane components from endosomes into the Golgi stacks and thereafter the ER. Within the peripheral portions of the latter system, the tracer molecules returned to close contact with the plasma membrane, but were not exposed on its surface, suggesting that no direct fusion took place. As discussed below, this does not exclude the possibility that integral membrane components (lipid or protein) may be exchanged between the ER and the plasma membrane at these sites. To what extent the internalization and spreading of CTB-HRP in the contractile cells repre- 

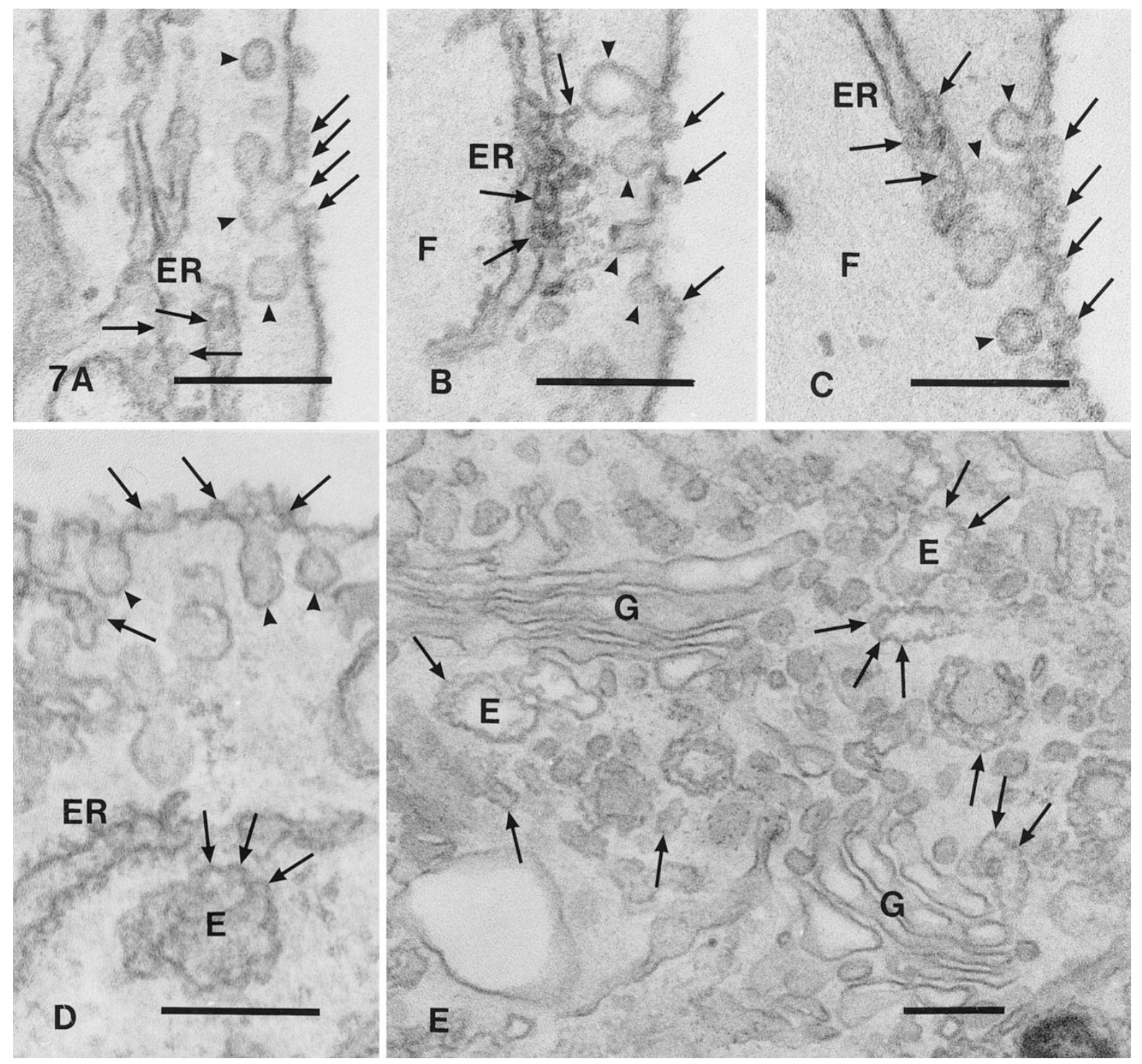

\section{Figure 7.}

Electron microscopy of smooth muscle cells grown in F12 medium with 10\% NCS for 2 days, fixed in glutaraldehyde, and exposed to $0.2 \mathrm{mg} / \mathrm{ml}$ of filipin for 10 hours before further processing ( $A$ to $E)$. Portions of contractile $(A, B$, and $C)$ and synthetic $(D$ and $E)$ cells are shown. Arrowheads mark caveolae and arrows mark filipin-sterol complexes. $E$, endosomes; $E R$, endoplasmic reticulum; $F$, myofilaments; $G$, Golgi stacks. Scale bars $=0.2 \mu \mathrm{m}$.

sent a normally ongoing membrane circulation or a process induced by binding of the tracer to $\mathrm{G}_{\mathrm{M} 1}$ ganglioside needs to be clarified. The differences in the ability of CTB-HRP to move retrogradely into the Golgi and ER of smooth muscle cells of the two phenotypes may be related to differences in secretory activity. The synthetic cells have a large ER and Golgi and actively produce extracellular matrix components (Thyberg, 1996). Hence, newly synthesized proteins are continually carried along the secretory path. In this situation, it is probably difficult to transport material from endosomes to trans-Golgi, backward through the cisternal stacks, and from cis-Golgi to the ER. In contractile cells, the secretory activity is low and the ER mainly functions in control of contraction by storage and release of calcium ions (Somlyo and Somlyo, 1994). Under these circumstances, retrograde trafficking through the Golgi stacks to the ER might be easier.

\section{LDL Uptake and Cholesterol Distribution}

Previous investigations have shown that vascular smooth muscle cells are able to internalize and degrade LDL and very low density lipoprotein (VLDL) (Campbell et al, 1983, 1985). However, the differences between cells in different phenotypes have not been fully clarified. Here, both contractile and synthetic cells ingested fluorescent LDL into endosome/lysosomes. Essentially all mammalian cells are similarly able to take up LDL by receptor-mediated endocytosis and transport the particles to lysosomes for enzymatic digestion and generation of free cholesterol. The free cholesterol molecules pass into the cytoplasm and are primarily used for membrane biogenesis (Brown and Goldstein, 1986). If accumulating in excess, free cholesterol may be esterified and stored in cytoplasmic lipid droplets. Alternatively, it may be captured by 


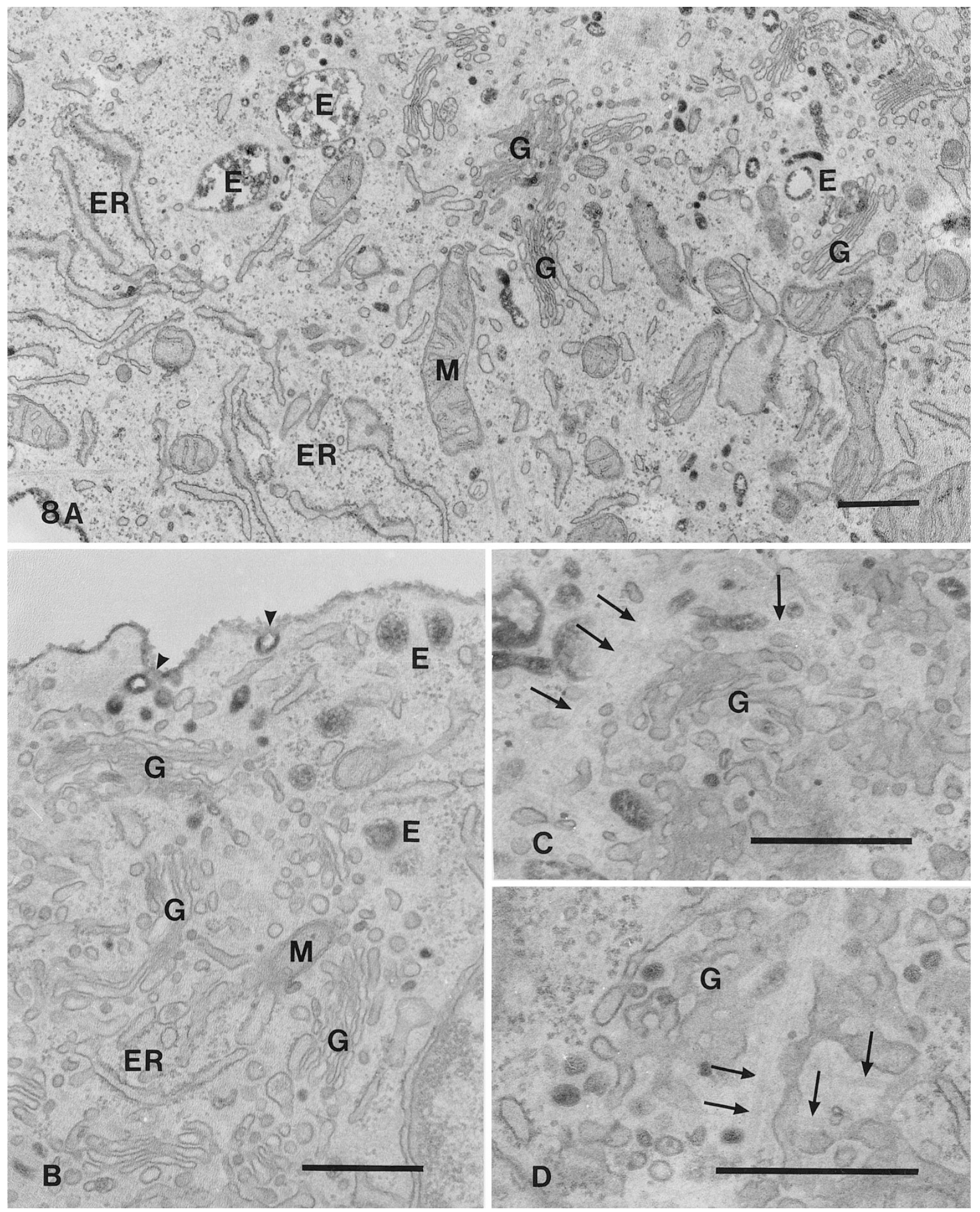

\section{Figure 8.}

Electron microscopy and demonstration of peroxidase activity in smooth muscle cells allowed to bind and internalize cholera toxin B subunit linked to horseradish peroxidase (CTB-HRP). The cells shown here were grown on a substrate of fibronectin in $\mathrm{F} 12$ medium with $0.1 \%$ BSA for 3 days and are all in a synthetic phenotype. In (A) and (B), cells were exposed to CTB-HRP for 30 minutes at $4^{\circ} \mathrm{C}$, rinsed, and then incubated in normal medium for 120 minutes at $37^{\circ} \mathrm{C}$. In (C) and (D), cells were exposed to CTB-HRP for 120 minutes at $37^{\circ} \mathrm{C}$. Arrowheads mark caveolae and arrows mark microtubules. E, endosomes; ER, endoplasmic reticulum; G, Golgi stacks; $M$, mitochondria. Scale bars $=0.5 \mu \mathrm{m}$.

caveolin-containing vesicles in the trans-Golgi network or heat-shock protein-caveolin complexes in the cytoplasm, transported to the plasma membrane, and expelled extracellularly by transfer from caveolae to high-density lipoprotein or other acceptors (Fielding and Fielding, 1995, 1996, 1997; Liscum and Munn, 1999; Uittenbogaard et al, 1998). The significance of this regulatory mechanism was affirmed by the finding 

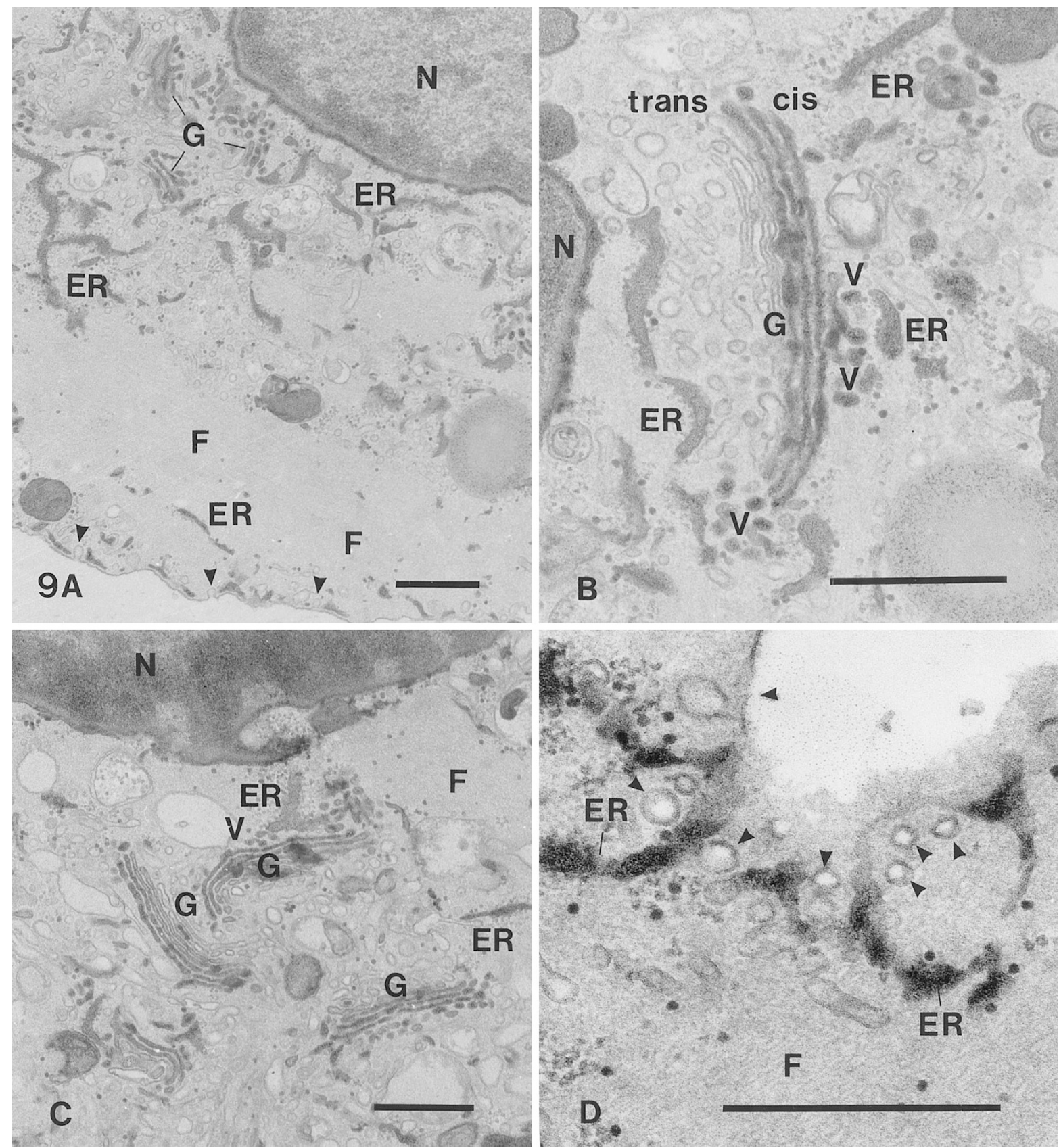

\section{Figure 9.}

Electron microscopy and demonstration of peroxidase activity in smooth muscle cells allowed to bind and internalize CTB-HRP. The cells shown here were grown on a substrate of fibronectin in F12 medium with $0.1 \%$ BSA for 1 day and are all in a contractile phenotype. They were exposed to CTB-HRP for 30 minutes at $4^{\circ} \mathrm{C}$, rinsed, and then incubated in normal medium for 120 minutes at $37^{\circ} \mathrm{C}$ (A to D). In the Golgi stacks, the tracer is concentrated on the outer, convex side (cis), and only weak reactivity is seen on the inner, concave side (trans). Labeled vesicles $(V$ are interposed between the Golgi stacks and adjacent cisternae of endoplasmic reticulum. Arrowheads mark caveolae. $E R$, endoplasmic reticulum; $F$, myofilaments; $G$, Golgi stacks; $N$, nucleus. Scale bars $=0.5 \mu \mathrm{m}$.

that caveolin mRNA levels in fibroblasts are upregulated by free cholesterol (Bist et al, 1997; Fielding et al, 1997). Likewise, caveolae numbers were increased in synthetic smooth muscle cells exposed to LDL, and filipin labeling verified that caveolae were enriched in cholesterol. Conceivably, formation of new caveolae in LDL-treated synthetic cells served as an attempt to deal with the cholesterol load. However, the cells frequently accumulated lipid droplets, indicating that they could not free themselves of all excess cholesterol as long as the LDL exposure lasted (Thyberg et al, 1998). In contractile cells, caveolae were numerous already under normal conditions and no further increase was detected after incubation with LDL, although the plasma membrane was strongly labeled with filipin. Moreover, cytoplasmic lipid droplets were seldom observed. Conceivably, this was an effect of the abundance of caveolae, making these cells able to expel large amounts of cholesterol (Thyberg et al, 1998). 
Table 1. Effects of LDL on Caveolae Expression in Contractile and Synthetic Smooth Muscle Cells*

\begin{tabular}{cccc}
\hline & & \multicolumn{2}{c}{ Statistical Significance } \\
\cline { 3 - 4 } Treatment & $\begin{array}{c}\text { Caveolae/ } \\
\mu \mathrm{m}\end{array}$ & $\begin{array}{c}\text { Control vs. } 1 \text { day vs. 4 } \\
\text { LDL } \\
\text { days }\end{array}$ \\
\hline Contractile cells & & & \\
Control (1 day) & $4.53(0.71)$ & $p>0.05$ & $p<0.001$ \\
LDL (1 day) & $4.60(0.78)$ & & $p<0.001$ \\
Synthetic cells & & & \\
Control (4 days) & $0.78(0.08)$ & $p<0.05$ & \\
LDL (4 days) & $1.64(0.82)$ & & \\
\hline
\end{tabular}

* Freshly isolated smooth muscle were cultured on a substrate of fibronectin in medium $\mathrm{F} 12 / 10 \% \mathrm{NCS}$ for 1 or 4 days, exposed to $\mathrm{LDL}(0.5 \mathrm{mg} / \mathrm{ml})$ in medium F12/0.5\% NCS for 6-8 hours, and processed for electron microscopy. Caveolae number on the upper cell surface was determined as described in the "Methods" section (only contractile cells were included in the 1-day-old and only synthetic cells in the 4-day-old cultures). The results are given as means of six experiments with standard deviation in parenthesis. The statistical significance of the differences of the means was analyzed using t-test.

In contractile cells, filipin-sterol complexes were prominent also in peripheral cisternae of the ER. These structures showed an intimate contact with plasma membrane caveolae, suggesting that cholesterol and/or other molecules may be transferred directly between the ER and caveolae. A similar but less conspicuous mechanism may exist in other cells and explain the rapid transport of newly synthesized cholesterol from the ER to the plasma membrane (Liscum and Munn, 1999). An interaction of this type could further explain how caveolin is redistributed from caveolae first to the ER and later to the Golgi complex after oxidation of plasma membrane cholesterol
(Smart et al, 1994). Additional filipin labeling was noted in endosomes/lysosomes and Golgi tubules or vesicles. The cholesterol in the membrane of the former structures may be derived from plasma membrane fragments internalized during endocytosis or from enzymatically digested lipoproteins. In contrast, no distinct filipin labeling of the Golgi cisternae was discerned, implying that these have a less important role than the surrounding tubulovesicular structures in cholesterol transport.

\section{Model of Caveolae Membrane and Cholesterol Transport in Smooth Muscle Cells}

The results of this study indicate that caveolae are more numerous and more actively interact with intracellular membrane systems in contractile than in synthetic smooth muscle cells (Fig. 10). Immunofluorescence and immunoelectron microscopy demonstrated that caveolin-1 was mainly localized to caveolae in contractile cells and partly shifted toward Golgiassociated vesicles in synthetic cells. On the other hand, caveolin-2 was chiefly found in cytoplasmic vesicles in both types of cells. Caveolin-3 showed a weaker staining and its distribution was difficult to evaluate in detail. Binding and internalization of CTBHRP primarily occurred via caveolae. In contractile cells, the tracer molecules were first transported to small Golgi-associated vesicles and larger endosomes or lysosomes. Subsequently, they were moved retrogradely into the stacked Golgi cisternae and all parts of the ER. In synthetic cells, no distinct labeling of Golgi and ER cisternae was detected and endosomes/lysosomes seemed to be the end station of the tracer. Thus, CTB-HRP had access to the endocytic as well as the exocytic pathway in contractile cells, but
Contractile phenotype

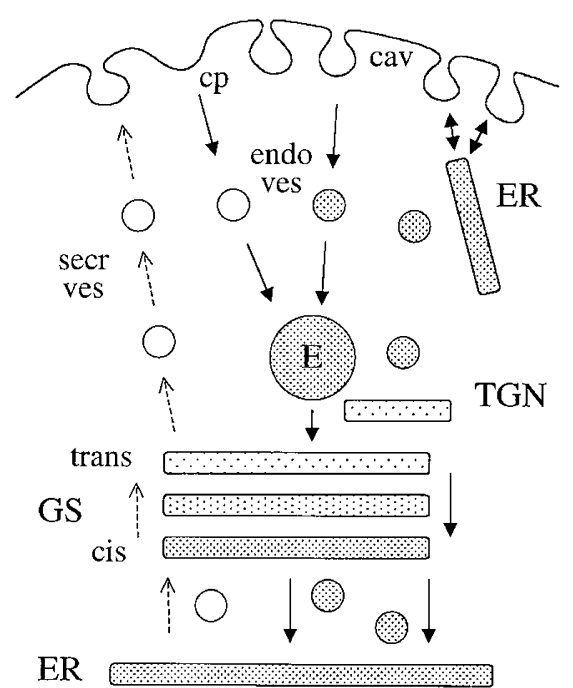

Synthetic phenotype

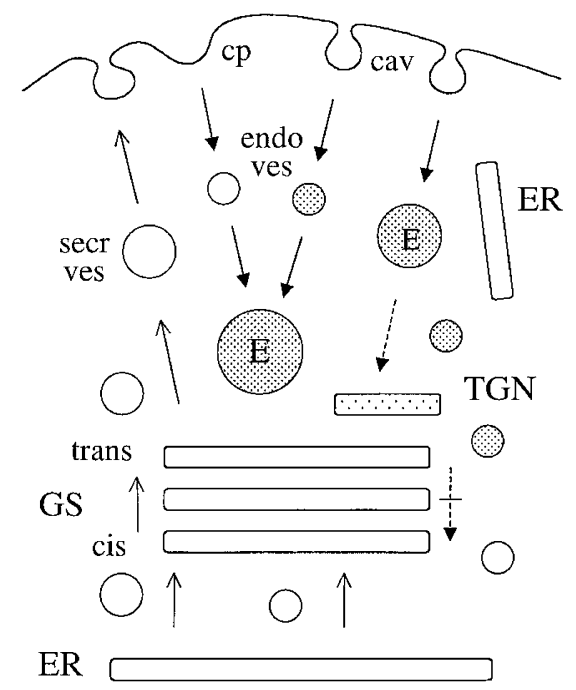

Figure 10.

Schematic model of differences in caveolae expression and dynamics in contractile and synthetic smooth muscle cells. The following structures are indicated: caveolae (cav); coated pits ( $c p)$; endocytic vesicles (endo ves); endoplasmic reticulum (ER); Golgi stacks (GS); secretory vesicles (secr ves); trans-Golgi network (TGM). The dotted pattern within membrane organelles represents internalized CTB-HRP. 
was restricted to the endocytic pathway in synthetic cells. In a similar manner, filipin labeling revealed that cholesterol was more widely distributed in contractile than in synthetic cells, with a strong labeling of caveolae as well as intracellular membranes. Of particular interest was the appearance of filipin-sterol complexes in peripheral parts of the ER, in close proximity to caveolae. Although no direct continuity between ER and caveolae could be demonstrated, it is suggested that cholesterol and/or other membrane components may be translocated between these compartments. The observed differences in caveolae expression and dynamics between contractile and synthetic smooth muscle cells are believed to be significant for the functional differences between these phenotypic states.

\section{Materials and Methods}

\section{Materials}

Ham's medium F12, newborn calf serum (NCS), and collagenase were from Gibco BRL (Paisley, Scotland), bovine serum albumin (BSA) from Sigma Chemical Co. (St. Louis, Missouri), and cell culture plasticware from Nunc (Roskilde, Denmark). The medium was supplemented with $10 \mathrm{~mm}$ Hepes, $10 \mathrm{~mm}$ Tes (pH 7.3), 50 $\mu \mathrm{g} / \mathrm{ml}$ of L-ascorbic acid, and $50 \mu \mathrm{g} / \mathrm{ml}$ of gentamycin sulfate (F12 medium). Fibronectin was isolated from human plasma on an affinity column of gelatinSepharose (Hedin and Thyberg, 1987). To prepare cell culture substrates, the protein was diluted to $10 \mu \mathrm{g} / \mathrm{ml}$ in Dulbecco's phosphate-buffered saline (PBS, pH 7.3), added to plastic dishes or glass coverslips, and allowed to adsorb for 15 to 20 hours at $20^{\circ} \mathrm{C}$. The dishes or coverslips were rinsed twice with PBS and incubated with F12 medium with $0.1 \%$ BSA for 30 minutes to block unspecific binding sites before the seeding of cells. Fluorescent human LDL (BODIPY FL LDL) was from Molecular Probes (Leiden, The Netherlands). Human LDL, CTB-HRP, horseradish peroxidase type II, CF, diaminobenzidine tetra- $\mathrm{HCl}$, filipin complex, mouse monoclonal antibodies against smooth muscle $\alpha$-actin and tyrosinated $\alpha$-tubulin, goat anti-mouse and anti-rabbit lgG linked to $10 \mathrm{~nm}$ colloidal gold particles, and rhodamine-labeled phalloidin were purchased from Sigma. Rabbit antibodies against caveolin and mouse monoclonal antibodies against caveolin-1 (clone 2297), caveolin-2 (clone 65), caveolin-3 (clone 26), and clathrin heavy chain (clone 23) were obtained from Transduction Laboratories (Mamhead, Exeter, United Kingdom). Rabbit antibodies against Golgi $\alpha$-mannosidase II (Moremen et al, 1991) were kindly provided by Dr. K.W. Moremen (University of Georgia, Athens, Georgia) and Dr. M.G. Farquhar (University of California, San Diego, California). Rhodamine-labeled swine anti-rabbit IgG and rabbit anti-mouse IgG were obtained from Dako (Glostrup, Denmark).

\section{Cell Culture}

Smooth muscle cells were isolated from the aortic media of 350 to $400 \mathrm{~g}$ male Sprague-Dawley rats by digestion with $0.1 \%$ collagenase in $\mathrm{F} 12$ medium with $0.1 \%$ BSA (Thyberg et al, 1990). After rinsing, the cells were normally seeded either on a substrate of fibronectin in F12 medium with $0.1 \%$ BSA $(40,000$ cells $/ \mathrm{cm}^{2}$ ) or directly in plastic dishes in $\mathrm{F} 12$ medium with $10 \%$ NCS $\left(25,000\right.$ cells $\left./ \mathrm{cm}^{2}\right)$. The cultures were incubated at $37^{\circ} \mathrm{C}$ in a humid atmosphere of $5 \% \mathrm{CO}_{2}$ in air, and medium was changed daily. To compare contractile and synthetic cells, the experiments were usually made in parallel on 1-day-old ( $>80 \%$ contractile cells) and 4-day-old (>80\% synthetic cells) cultures (see Hedin et al, 1988; Thyberg et al, 1983).

\section{Exposure to BODIPY FL LDL}

Freshly isolated smooth muscle cells were seeded on glass coverslips in F12 medium with $2 \%$ NCS $(40,000$ cells $/ \mathrm{cm}^{2}$ ) or on fibronectin-coated glass coverslips in F12 medium with $0.1 \%$ BSA $\left(40,000\right.$ cells $\left./ \mathrm{cm}^{2}\right)$. After 1 or 4 days of culture, the cells were rinsed twice with F12 medium with $0.1 \%$ BSA and exposed to $50 \mu \mathrm{g} / \mathrm{ml}$ of BODIPY FL LDL in this medium for 90 minutes at $37^{\circ} \mathrm{C}$. Cells were then rinsed three times with cold F12 medium with $0.1 \%$ BSA and fixed in $2 \%$ formaldehyde in PBS for 2 hours. The coverslips were rinsed three times with PBS, mounted on glass slides in a glycerolbased medium with anti-fading agent, and examined in a Nikon Labophot microscope.

\section{Exposure to CTB-HRP}

Freshly isolated smooth muscle cells were seeded in fibronectin-coated dishes in F12 medium with $0.1 \%$ BSA $\left(40,000\right.$ cells $\left./ \mathrm{cm}^{2}\right)$. After 1,2 , or 3 days of culture, the cells were rinsed with $\mathrm{F} 12$ medium with $0.1 \% \mathrm{BSA}$ and exposed to CTB-HRP ( 1 to $2 \mu \mathrm{g} / \mathrm{ml}$ of CTB) in this medium for $10,30,60$, or 120 minutes at $37^{\circ} \mathrm{C}$. Alternatively, the cells were first exposed to CTB-HRP for 30 minutes at $4^{\circ} \mathrm{C}$, rinsed three times with cold medium, and then incubated in fresh medium for 30 or 120 minutes at $37^{\circ} \mathrm{C}$. For comparative purposes, the cells were also incubated with $1 \mathrm{mg} / \mathrm{ml}$ of HRP or 0.1 $\mathrm{mg} / \mathrm{ml}$ of CF for 120 minutes at $37^{\circ} \mathrm{C}$. After the tracer incubations, the cells were fixed in $3 \%$ cacodylatebuffered glutaraldehyde ( $\mathrm{pH}$ 7.3) for 1 hour and rinsed in buffer. Peroxidase activity was demonstrated by incubation with $0.5 \mathrm{mg} / \mathrm{ml}$ of diaminobenzidine tetra$\mathrm{HCl}$ and $0.01 \% \mathrm{H}_{2} \mathrm{O}_{2}$ in $0.05 \mathrm{M}$ Tris- $\mathrm{HCl}$ buffer $(\mathrm{pH} 7.6)$ for 45 minutes at $20^{\circ} \mathrm{C}$. After rinsing, the cells were scraped off the dishes, transferred to plastic tubes, and further processed for electron microscopy. In control cells not exposed to CTB-HRP, reaction product was sometimes noted in mitochondria (especially in contractile cells). Otherwise, no endogenous peroxidase activity was detected.

\section{Electron Microscopy}

The cells were fixed in $3 \%$ glutaraldehyde in $0.1 \mathrm{M}$ sodium cacodylate- $\mathrm{HCl}$ buffer $(\mathrm{pH} 7.3)$ with $0.05 \mathrm{M}$ 
sucrose for 2 hours or more, scraped off the dishes with a plastic spatula, transferred to plastic tubes, and pelleted by centrifugation. After rinsing, the specimens were postfixed in $1.5 \%$ osmium tetroxide in $0.1 \mathrm{M}$ cacodylate buffer ( $\mathrm{pH} 7.3$ ) with $0.5 \%$ potassium ferrocyanate for 2 hours at $4^{\circ} \mathrm{C}$, dehydrated in ethanol $(70$, $95,100 \%)$, stained with $2 \%$ uranyl acetate in ethanol, and embedded in Spurr low viscosity epoxy resin. Sections of uniform thickness were cut with diamond knives on an LKB Ultrotome iv, picked up on carboncoated formvar films, stained with alkaline lead citrate, and examined in a Philips CM120Twin EM at $80 \mathrm{kV}$ (Philips, Eindhoven, The Netherlands). For quantitative evaluation of caveolae expression, one large section from each specimen was scanned systematically, and mid-sagittal sections through the central parts of the cells (extending from the nucleus toward the periphery) were photographed at a final magnification of $\times 35,000$. The number of caveolae on the upper cell surface was counted and the length of the plasma membrane within the plane of section was measured using a digital instrument (Calculated Industries, Yorba Linda, California). To assess the relative cholesterol content of different cellular membranes, the cultures were exposed to $0.2 \mathrm{mg} / \mathrm{ml}$ of filipin (first dissolved in a droplet of DMSO) in $0.1 \mathrm{M}$ cacodylate buffer ( $\mathrm{pH}$ 7.3) for 10 hours after the glutaraldehyde fixation and before removing the cells from the dishes (Orci et al, 1981). Thereafter, the above protocol was followed.

\section{Immunoelectron Microscopy}

The cultures were fixed for 2 hours in $2 \%$ formaldehyde with $0.1 \%$ glutaraldehyde in PBS ( $\mathrm{pH} 7.3)$. After rinsing in PBS, the cells were scraped off the dishes and sedimented by centrifugation (12,000 rpm for 20 minutes). The resulting pellet was cut into small pieces, postfixed in $0.2 \%$ osmium tetroxide in $0.1 \mathrm{M}$ cacodylate buffer ( $\mathrm{pH} 7.3$ ) with $0.3 \%$ potassium ferrocyanate for 30 minutes at $4^{\circ} \mathrm{C}$, dehydrated in ethanol $(70,95,100 \%)$, and embedded in LR White (London Resin Company, Reading, United Kingdom). The specimens were incubated in a mixture of equal parts ethanol and LR White (v/v) for 30 minutes and then left in pure resin for 15 hours at $4^{\circ} \mathrm{C}$. After two new incubations in LR White (30 minutes each), specimens were put into gelatin capsules filled with resin and placed in an UV polymerization unit (Agar Scientific, Stansted, United Kingdom) for 12 to 15 hours. Thin sections were cut with diamond knives and picked up on nickel grids coated with a carbon-stabilized formvar film. For immunogold staining, the grids were placed on droplets of PBS with 6\% BSA and $0.01 \%$ Tween 20 for 60 minutes to block unspecific binding sites. They were then transferred to primary antibodies diluted in PBS with 6\% BSA and 0.01\% Tween 20 and incubated for 2 to 3 hours in a humid atmosphere. After rinsing with PBS with 6\% BSA and $0.01 \%$ Tween 20 , they were placed on droplets of gold-labeled secondary antibodies diluted in PBS with 3\% BSA for 1 to 2 hours, rinsed with PBS with $3 \%$ BSA, rinsed with PBS, postfixed with $2 \%$ glutaraldehyde in PBS for 5 minutes, rinsed with PBS, rinsed with water, and air-dried. Controls without primary antibodies and with unrelated mouse or rabbit lgG were negative. Contrast staining was made with aqueous uranyl acetate for 30 minutes and alkaline lead citrate for 30 seconds.

\section{Filipin Staining and Immunofluorescence Microscopy}

Cells grown on glass coverslips were fixed in $2 \%$ formaldehyde in PBS ( $\mathrm{pH} 7.3)$ for 60 minutes, rinsed with PBS, and stored in PBS with $0.02 \%$ sodium azide at $4^{\circ} \mathrm{C}$ before use. To demonstrate cellular cholesterol, the coverslips were exposed to $0.5 \mathrm{mg} / \mathrm{ml}$ of filipin (diluted with PBS from $2.5 \mathrm{mg} / \mathrm{ml}$ of stock solution in DMSO) in a humidified chamber for 15 hours at $20^{\circ} \mathrm{C}$, rinsed three times with PBS, and mounted on glass slides in a glycerol-based medium. For immunostaining, the cells were treated with $50 \mathrm{~mm}$ ammonium chloride in PBS for 15 minutes and permeabilized with $0.2 \%$ Triton X-100 in PBS for 2 to 3 minutes. They were thereafter exposed to primary and secondary antibodies for 90 minutes each (diluted in PBS with $0.2 \%$ BSA). The coverslips were mounted in a glycerol-based medium with triethylenediamine as anti-fading agent. The specimens were examined in a Nikon Labophot microscope with epifluorescence optics. Controls incubated without filipin or primary antibodies or with unspecific mouse or rabbit lgG were negative.

\section{Acknowledgement}

The author thanks Karin Blomgren for expert technical assistance.

\section{References}

Anderson RGW (1998). The caveolae membrane system. Annu Rev Biochem 67:199-225.

Bist A, Fielding PE, and Fielding CJ (1997). Two sterol regulatory element-like sequences mediate up-regulation of caveolin gene transcription in response to low density lipoprotein free cholesterol. Proc Natl Acad Sci USA 94: 10693-10698.

Börnig $H$ and Geyer $G$ (1974). Staining of cholesterol with the fluorescent antibiotic filipin. Acta Histochem 50:110-115.

Brown MS and Goldstein JL (1986). A receptor-mediated pathway for cholesterol homeostasis. Science 232:34-47.

Campbell JH, Popadynec L, Nestel PJ, and Campbell GR (1983). Lipid accumulation in arterial smooth muscle cells. Influence of phenotype. Atherosclerosis 47:279-295.

Campbell JH, Reardon MF, Campbell GR, and Nestel PJ (1985). Metabolism of atherogenic lipoproteins by smooth muscle cells of different phenotype in culture. Arteriosclerosis 5:318-328.

Conrad PA, Smart EJ, Ying Y-S, Anderson RGW, and Bloom GS (1995). Caveolin cycles between plasma membrane caveolae and the Golgi complex by microtubule-dependent and microtubule-independent steps. J Cell Biol 131:14211433. 
Critchley DR, Streuli CH, Kellie S, Ansell S, and Patel B (1982). Characterization of the cholera toxin receptor on $\mathrm{Balb} / \mathrm{c}$ 3T3 cells as a ganglioside similar to, or identical with, ganglioside GM1. Biochem J 204:209-219.

Fielding PE and Fielding CJ (1995). Plasma membrane caveolae mediate the efflux of cellular free cholesterol. Biochemistry 34:14288-14292.

Fielding PE and Fielding CJ (1996). Intracellular transport of low density lipoprotein derived free cholesterol begins at clathrin-coated pits and terminates at cell surface caveolae. Biochemistry 35:14932-14938.

Fielding CJ and Fielding PE (1997). Intracellular cholesterol transport. J Lipid Res 38:1503-1521.

Fielding CJ, Bist A, and Fielding PE (1997). Caveolin mRNA levels are up-regulated by free cholesterol and downregulated by oxysterols in fibroblast monolayers. Proc Natl Acad Sci USA 94:3753-3758.

Gu F and Gruenberg J (1999). Biogenesis of transport intermediates in the endocytic pathway. FEBS Lett 452:61-66.

Hedin U, Bottger BA, Forsberg E, Johansson S, and Thyberg $\mathrm{J}$ (1988). Diverse effects of fibronectin and laminin on phenotypic properties of cultured arterial smooth muscle cells. J Cell Biol 107:307-319.

Hedin U and Thyberg J (1987). Plasma fibronectin promotes modulation of arterial smooth-muscle cells from contractile to synthetic phenotype. Differentiation 33:239-246.

Henley JR, Krueger EWA, Oswald BJ, and McNiven MA (1998). Dynamin-mediated internalization of caveolae. J Cell Biol 141:85-99.

Kruth HS and Vaughan M (1980). Quantification of low density lipoprotein binding and cholesterol accumulation by single human fibroblasts using fluorescence microscopy. J Lipid Res 21:123-130.

Lencer WI, Hirst TR, and Holmes RK (1999). Membrane traffic and the cellular uptake of cholera toxin. Biochim Biophys Acta 1450:177-190.

Liscum L and Munn NJ (1999). Intracellular cholesterol transport. Biochim Biophys Acta 1438:19-37.

Luetterforst R, Stang E, Zorzi N, Carozzi A, Way M, and Parton RG (1999). Molecular characterization of caveolin association with the Golgi complex: Identification of a cisGolgi targeting domain in the caveolin molecule. J Cell Biol 145:1443-1459.

Marsh M and McMahon T (1999). The structural era of endocytosis. Science 285:215-220.

Mellman I (1996). Endocytosis and molecular sorting. Annu Rev Cell Dev Biol 12:575-625.

Montesano R, Roth J, Robert A, and Orci L (1982). Noncoated membrane invaginations are involved in binding and internalization of cholera and tetanus toxins. Nature 296:651653.

Mora R, Bonilha VL, Marmorstein A, Scherer PE, Brown D, Lisanti MP, and Rodriguez-Boulan E (1999). Caveolin-2 localizes to the Golgi complex but redistributes to plasma membrane, caveolae, and rafts when co-expressed with caveolin-1. J Biol Chem 274:25708-25717.

Moremen KW, Touster O, and Robbins PW (1991). Novel purification of the catalytic domain of Golgi $\alpha$-mannosidase
II: Characterization and comparison with the intact enzyme. J Biol Chem 266:16876-16885.

Murata M, Peränen J, Schreiner R, Wieland F, Kurzchalia TV, and Simons K (1995). VIP21 caveolin is a cholesterol-binding protein. Proc Natl Acad Sci USA 92:10339-10343.

Oh P, Mclntosh DP, and Schnitzer JE (1998). Dynamin at the neck of caveolae mediates their budding to form transport vesicles by GTP-driven fission from the plasma membrane of endothelium. J Cell Biol 141:101-114.

Orci L, Montesano R, Meda P, Malaisse-Lagae F, Brown D, Perrelet A, and Vassalli $P$ (1981). Heterogeneous distribution of filipin-cholesterol complexes across the cisternae of the Golgi apparatus. Proc Natl Acad Sci USA 78:293-297.

Orlandi PA and Fishman PH (1998). Filipin-dependent inhibition of cholera toxin: Evidence for toxin internalization and activation through caveolae-like domains. J Cell Biol 141: 905-915.

Owens GK (1995). Regulation of differentiation of vascular smooth muscle cells. Physiol Rev 75:487-517.

Parolini I, Sargiacomo M, Galbiati F, Rizzo G, Grignani F, Engelman JA, Okamoto T, Ikezu T, Scherer PE, Mora R, Rodriguez-Bolan E, Peschle C, and Lisanti MP (1999). Expression of caveolin-1 is required for the transport of caveolin-2 to the plasma membrane. Retention of caveolin-2 at the level of the Golgi complex. J Biol Chem 274:2571825725.

Parton RG (1994). Ultrastructural localization of gangliosides; GM1 is concentrated in caveolae. J Histochem Cytochem 42:155-166.

Sandvig K, Garred Ø, and van Deurs B (1996). Thapsigargininduced transport of cholera toxin to the endoplasmic reticulum. Proc Natl Acad Sci USA 93:12339-12343.

Sandvig K, Ryd M, Garred Ø, Schweda E, Holm PK, and van Deurs B (1994). Retrograde transport from the Golgi complex to the ER of both Shiga toxin and the nontoxic Shiga $\mathrm{B}$-fragment is regulated by butyric acid and cAMP. J Cell Biol 126:53-64.

Scherer PE, Lewis RY, Volonté D, Engelman JA, Galbiati F, Couet J, Kohtz DS, van Donselaar E, Peters P, and Lisanti MP (1997). Cell-type and tissue-specific expression of caveolin-2. Caveolins 1 and 2 co-localize and form a stable hetero-oligomeric complex in vivo. J Biol Chem 272:2933729346.

Schnitzer JE, Liu J, and Oh P (1995). Endothelial caveolae have the molecular transport machinery for vesicle budding, docking, and fusion including VAMP, NSF, SNAP, annexins, and GTPases. J Biol Chem 270:14399-14404.

Schnitzer JE, Oh P, and Mclntosh DP (1996). Role of GTP hydrolysis in fission of caveolae directly from plasma membranes. Science 274:239-242.

Simionescu N, Lupu F, and Simionescu M (1983). Rings of membrane sterols surround the openings of vesicles and fenestrae in capillary endothelium. J Cell Biol 97:1592-1600.

Smart EJ, Graf GA, McNiven MA, Sessa WC, Engelman JA, Scherer PE, Okamoto T, and Lisanti MP (1999). Caveolins, liquid-ordered domains, and signal transduction. Mol Cell Biol 19:7289-7304.

Smart EJ, Ying Y-S, Conrad PA, and Anderson RGW (1994). Caveolin moves from caveolae to the Golgi apparatus in response to cholesterol oxidation. J Cell Biol 127:1185-1197. 
Smart EJ, Ying Y-S, Donzell WC, and Anderson RGW (1996). A role for caveolin in transport of cholesterol from endoplasmic reticulum to plasma membrane. J Biol Chem 271:2942729435.

Somlyo AP and Somlyo AV (1994). Signal transduction and regulation in smooth muscle. Nature 372:231-236.

Song KS, Scherer PE, Tang ZL, Okamoto T, Li S, Chafel M, Chu C, Kohtz DS, and Lisanti MP (1996). Expression of caveolin-3 in skeletal, cardiac, and smooth muscle cells. Caveolin-3 is a component of the sarcolemma and cofractionates with dystrophin and dystrophin-associated glycoproteins. J Biol Chem 271:15160-15165.

Thyberg J (1996). Differentiated properties and proliferation of arterial smooth muscle cells in culture. Int Rev Cytol 169:183-265.

Thyberg J (1998). Phenotypic modulation of smooth muscle cells during formation of neointimal thickenings following vascular injury. Histol Histopathol 13:871-891.

Thyberg J, Calara F, Dimayuga P, Nilsson J, and Regnström $J$ (1998). Role of caveolae in cholesterol transport in arterial smooth muscle cells exposed to lipoproteins in vitro and in vivo. Lab Invest 78:825-837.
Thyberg J, Hedin U, and Bottger BA (1990). Attachment substrates for smooth muscle cells. In: Piper HM, editor. Cell culture techniques in heart and vessel research. Berlin: Springer-Verlag, 315-333.

Thyberg J, Palmberg L, Nilsson J, Ksiazek T, and Sjölund M (1983). Phenotype modulation in primary cultures of arterial smooth muscle cells. On the role of platelet-derived growth factor. Differentiation 25:156-167.

Thyberg J, Roy J, Tran PK, Blomgren K, Dumitrescu A, and Hedin U (1997). Expression of caveolae on the surface of rat arterial smooth muscle cells is dependent on the phenotypic state of the cells. Lab Invest 77:93-101.

Tran D, Carpentier J-L, Sawano F, Gorden P, and Orci L (1987). Ligands internalized through coated or noncoated invaginations follow a common intracellular pathway. Proc Natl Acad Sci USA 84:7957-7961.

Uittenbogaard A, Ying Y, and Smart EJ (1998). Characterization of a cytosolic heat-shock protein-caveolin chaperone complex. Involvement in cholesterol trafficking. J Biol Chem 273:6525-6532. 